\title{
PENGEMBANGAN STRATEGI PEMBELAJARAN PENDIDIKAN AGAMA ISLAM (PAI) DALAM MERESPON ERA DIGITAL
}

\author{
Muhammad Tang \\ Sekolah Tinggi Agama Islam (STAI) Al-Furqan Makassar \\ Muhammadtang.mt78@gmail.com
}

\begin{abstract}
In today's digital era, people generally think that the current learning of Islamic Religious Education (PAI) has been considered a failure to instill moral / religious values to learners. This can be seen by the many crimes committed by teenagers who are students. For example; begal, drug abuse, brawl, promiscuity and other forms of crime. The failure of learning PAI, according to the author one of the reasons is because in general learning PAI done in monotonous and conventional. Therefore, as PAI educators / teachers should be innovative and creative in developing learning strategies that are interesting and fun for learners. So the values of Islamic education can be well internalized in the learners. This paper comes to dissect and offer the concept of PAI learning strategies that are integrative in response to the development of technological tools in the digital era today. This paper uses the method of library research with a criticalanalysis approach, thus giving birth to a concept or model of learning strategy that is integrative between religious values, science and technology.
\end{abstract}

Key words: PAI, integrative strategy, digital era.

\begin{abstract}
Abstrak
Di era digital saat ini, orang-orang umumnya berpikir bahwa pembelajaran Pendidikan Agama Islam (PAI) saat ini telah dianggap sebagai kegagalan untuk menanamkan nilai-nilai moral / religius kepada peserta didik. Hal ini dapat dilihat dari banyaknya kejahatan yang dilakukan oleh remaja. Sebagai contoh; begal, penyalahgunaan narkoba, tawuran, pergaulan bebas dan bentuk-bentuk kejahatan lainnya. Kegagalan belajar PAI, menurut penulis salah satu alasannya adalah karena secara umum pembelajaran PAI dilakukan secara monoton dan konvensional. Oleh karena itu, sebagai pendidik PAI / guru harus inovatif dan kreatif dalam mengembangkan strategi pembelajaran yang menarik dan menyenangkan bagi peserta didik. Jadi nilai-nilai pendidikan Islam dapat terinternalisasi dengan baik di dalam peserta didik. Makalah ini membedah dan menawarkan konsep strategi pembelajaran PAI yang integratif dalam menanggapi perkembangan media teknologi di era digital saat ini. Tulisan ini
\end{abstract}


Muhammad Tang, Pengembangan Strategi Pembelajaran Pendidikan Agama Islam (PAI) dalam Merespon Era Digital

menggunakan metode penelitian perpustakaan dengan pendekatan analisis kritis, sehingga melahirkan konsep atau model strategi pembelajaran yang integratif antara nilai-nilai agama, sains dan teknologi.

Kata Kunci: PAI, strategi integratif, era digital.

\section{Pendahuluan}

Dunia Islam sekarang ini terpuruk dibandingkan dengan dunia Barat (non Muslim). Menurut Ismail Raji al-Faruqi dalam Sutrisno, bahwa umat Islam sekarang benar-benar terpuruk dan terhina baik secara fisik maupun mental. Citra umat Islam selalu dipojokkan dengan sebutan agresif, destruktif, ekstremis, ekslusif, mengingkari hukum, teroris, biadab, fanatik, fundamentalis, dan dunianya selalu dipenuhi pertentangan, perpecahan, peperangan, serta diklaim sebagai dunia yang sakit. ${ }^{1}$

Indonesia merupakan negara yang jumlah penduduk umat Islam terbesar di dunia. Namun, kebesaran itu hanya bersifat kuantitatif tidak diikuti dengan tingkat kualitas umat. Hal ini dapat dilihat tingkat kualitas umat sekarang ini. Dari semua lini kehidupan, umat Islam bertindak sebagai pemakai/konsumen tanpa mampu bertindak sebagai produsen/penghasil. Apakah itu di bidang ekonomi, elektronika dan informatika, di bidang farmasi dan kedokteran, atau di bidang sains dan teknologi dan bidang lainya. Intinya, umat Islam sekarang ini mengalami keterpurukan; baik keterpurukan akhlak dan moral maupun keterpurukan dari segi sumber daya manusianya (SDM). Rendahnya moral dan SDM umat Islam khususnya di Indonesia dan umat Islam pada umumnya sekarang ini, maka yang bertanggung jawab adalah dunia pendidikan, khususnya pendidikan Islam.

Pendidikan Agama Islam (PAI) sebagai salah satu mata pelajaran yang diajarkan di sekolah/madrasah/pesantren memiliki peranan yang sangat strategis untuk membentuk kepribadian umat dan bangsa (peserta didik) yang tangguh; baik dari segi moralitas maupun dari aspek sains dan teknologi. Namun, kenyatan yang kita lihat sekarang ini pembelajaran PAI di sekolah/madrasah/pesantren maupun di perpendidikan tinggi menjadi sorotan pada masyarakat atau para pakar pendidikan bahwa pembelajaran PAI kurang berhasil dalam menanamkan nilai-nilai moral dan agama kepada peserta didik. Hal ini dapat dilihat maraknya terjadi fatologi sosial pada remaja

\footnotetext{
${ }^{1}$ Ismail Raji al-Faruki dalam Sutrisno, Pendidikan Islam yang menghidupkan: Studi Kritis Terhadap Pemikiran Fazlurrahman (Yogyakarta: Kota Kembang, 2006), 1.
} 
(pelajar), seperti penyalagunaan Narkoba, begal, pergaulan bebas dan tawuran, serta penyakit sosial lainnya. Kesemua itu merupakan bukti yang menguatkan bahwa pola strategi pembelajaran PAI di sekolah/madrasah dewasa ini berjalan secara konvensional-tradisional serta penuh dengan keterbatasan.

Keterbatasan strategi pembelajaran PAI dewasa ini di sekolah, bukan hanya dari aspek materi dan metodeloginya saja, akan tetapi seluruh aspek perlu mendapat kajian secara mendalam dan konprehensif. Misalnya, keprofesionalan pendidik PAI dalam melaksanakan proses pembelajaran, materi PAI terkesan didominasi hal-hal yang bersifat normatif, ritualistik, eskatologis. Hal ini senada yang diungkapkan Musa Asy'arie, bahwa pendidikan agama di sekolah lebih menguatnya penekanan pada formalisme agama, normatif, dan tekstual yang terlepas dari konteksnya. ${ }^{2}$

Di samping itu, pengembangan pembelajaran PAI sekarang ini kurang merespon perkembangan zaman/era digital. Pada hal apabila kita lihat realitas peserta didik sekarang ini, mereka pada umumnya sangat akrab dengan alat digital seperti, hand phone smart, laptop, dan alat digital lainnya. Seyogyanya, sebagai seorang pendidik/pendidik PAI yang responsif melihat kondisi tersebut akan bersikap inovatif dan kreatif mengembangkan strategi pembelajaran yang sesuai dengan dunia anak-anak (peserta didik) sekarang ini.

Melihat masalah tersebut di atas, perlu di kembangkan strategi pembelajaran PAI yang bersifat integratif sebagai suatu solusi dalam mengatasi masalah tersebut. Sehingga pembeajaran PAI di sekolah/madrasah/pesantren dapat lebih bermakna dan merespon perkembangan era digital.

Tulisan ini hadir sebagai respon terhadap masalah tersebut, dengan menguraikan beberapa sub pembahasan, yaitu; Landasan teori Pengemabangan Strategi Pembelajaran, Konsep Dasar Strategi Pembelajaran, dan Langkah-Langkah Strategis untuk Mengembangkan Strategi Pembelajaran PAI dalam Merespon Era Digital.

Untuk membahas sub-sub pembahasan tersebut, penulis menggunakan metodologi kualitatif berbasis library research dengan pendekatan analisis-kritis bersifat deskriptif. Dengan menghasilkan suatu model strategi pembelajaran PAI yang bersifat integratif (religi, sains dan teknologi) yang dapat merespon perkembangan zaman/era digital.

\footnotetext{
${ }^{2}$ Musa Asy’arie, NKRI, Budaya Politik dan Pendidikan (Yogyakarta: LESFI, 2005),. 190.
} 
Muhammad Tang, Pengembangan Strategi Pembelajaran Pendidikan Agama Islam (PAI) dalam Merespon Era Digital

\section{Landasan Teori Pengembangan Strategi Pembelajaran}

Pengembangan strategi pembelajaran memerlukan landasan teori agar hasil pengembangannya dapat terarah dan sesuai apa yang diinginkan. Dalam kajian ini, penulis menggunakan teori yang dikembangkan Crowl, Kaminsky \& Podell dalam Sri Anita W, menjelaskan tiga teori yang menjadi landasan pengembangan strategi pembelajaran, yaitu; (1) Pengalaman belajar yang dikembangkan oleh Gagne (2) . Discovery learning yang dikembangkan oleh Bruner, yang mengarahkan proses pembelajaran dimulai dari problem solving dari pendidik untuk meningkatkan kemampuan peseerta didik dalam mengkaji dan mendeskripsikan pemecahan masalahnya; (3). Advance Organizers yang dikembangkan oleh Ausubel, suatu argumen yang memberikan arahan dan membantu pesrta didik untuk mempersiapkan pembelajaran dan memberikan pedoman korelasi antara apa yang akan dipelajari dengan konstruk (konsep) atau ide yang lebih komprehensif. ${ }^{3}$

Berikut ini akan dijelaskan landasan teori tersebut, untuk memberikan deskripsi tentang subtansi pengembangan strategi pembelajaran. Pertama, Pengalaman atau peristiwa-peristiwa Belajar yang dikembangkan Gagne Gagne \& Driscoll dalam Sri Witah W mengembangkan suatu model berdasarkan teori peroses informasi yang memandang pembelajaran memiliki 9 urutan pengalaman atau peristiwa, yaitu; (1). Menarik perhatian peserta didik. (2). Mengemukakan tujuan pembelajaran. (3). Memunculkan pengetahuan awal. (4). Menyajikan bahan stimulasi. (5). Membimbing belajar. (6). Menerima respons peserta didik. (7). Memberikan umpan balik. (8). Menilai unjuk kerja. (9). Meningkatkan retensi dan transfer. ${ }^{4}$

Konsep Gagne \& Driscoll tersebut memberikan gambaran secara sistematis proses pembelajaran yang dapat menjadi landasan pengembangan strategi pembelajaran. Dalam mengembangkan strategi pembelajaran berdasarkan konsep Gagne \& Driscoll landasannya adalah proses informasi yang disampaikan kepada peserta didik mulai awal pembelajaran sampai pada tahap akhir pembelajaran. Dalam proses tersebut tergambar bahwa langkah awal yang harus dilakukan oleh pendidik adalah bagaimana menarik perhatian peserta didik dengan memberikan gambaran atau tujuan yang akan dicapai dalam pembelajaran. Disamping itu, agar peserta didik dapat aktif dalam proses

\footnotetext{
${ }^{3}$ Sri Anitah W., Strategi Pembelajaran, PEFI4201/MODUL 1, t.th., 1.5.

${ }^{4}$ Sri Witah W., Strategi..., 1.6.
} 
pembelajaran harus diberikan stimulus dan responsif terhadap pertanyaan yang diberikan oleh peserta didik. Kemudian segala tugas yang diberikan kepada peserta didik harus diperiksa dengan baik (memberikan nilai) sesuai dengan tingkat kemampuannya. Selanjutnya yang terakhir adalah bahwa setiap proses pembelajaran harus ada peningkatan retensi atau progres capaian.

Kedua, pemandu awal (Advance Organizer), dalam melaksanakan proses pembelajaran, Pendidik dianjurkan untuk menggunakan pemandu awal untuk memberikan stimulus atau mengaktifkan skemata peserta didik (eksistensi pemahaman peserta didik), untuk mengetahui apa yang telah diketahui atau apa yang dipahami peserta didik, dan untuk membantu peserta didik memahami korelasi pengetahuan yang telah dimiliki. pemandu awal menjelaskan pemahaman baru secara umum yang dapat digunakan peserta didik sebagai kerangka untuk memahami isi informasi baru secara rinci. Pendidik dapat menggunakan pemandu awal untuk mengajar dalam berbagai bidang studi.

Ketiga, discovery learning yang dikembangkan oleh Bruner. Discovery (penemuan) merupakan teori belajar yang dikembangkan Bruner yang mengasumsikan bahwa belajar paling baik apabila peserta didik menemukan sendiri informasi dan konstruk (konsep) dalam pembelajaran. Dalam belajar discovery, peserta didik menggunakan penalaran induktif untuk mendapatkan prinsip-prinsip, contoh-contoh. Misalnya, pendidik menjelaskan kepada peserta didik tentang penemuan kamera, $\mathrm{CD}$, telephone, tv, televisi, sinar lampu pijar,dan penemuan lainnya, serta perbandingan antara invention dengan discovery (misalnya, listrik, nuklir, dan gravitasi). Peserta didik, kemudian menjabarkan sendiri apakah yang dimaksud dengan invention dan bagaimana perbedaannya dengan discovery.

Discovery, peserta didik menemukan konstruk (konsep) dasar atau prinsipprinsip dengan melaksanakan kegiatan-kegiatan yang mempraktekkan konsep tersebut. Bruner yakin bahwa peserta didik akan memiliki pengetahuan apabila menemukan sendiri dan bertanggung jawab atas kegiatan belajarnya sendiri, yang mendoromgnya untuk belajar.

Keempat, meaningfull learning (Belajar Bermakna) yang dikembangkan Ausubel. Ausubel mengarahkan untuk mengimplementasikan interaksi aktif antara pendidik dengan peserta didik yang disebut belajar verbal yang bermakna (meaningfulf 
Muhammad Tang, Pengembangan Strategi Pembelajaran Pendidikan Agama Islam (PAI) dalam Merespon Era Digital

verbal learning) atau disebut dengan belajar bermakna. Proses pembelajaran ini menekankan pada ekspositori dengan cara, pendidik menyajikan materi secara eksplisit dan terorganisir. Dalam proses pembelajaran ini, peserta didik menerima serangkaian ide yang disajikan pendidik dengan cara yang efisien.

Teori Ausubel ini menekankan pada penalaran yang bersifat deduktif, yang mengharuskan peserta didik pertama-tama mempelajari prinsip-prinsip yang bersifat umum, kemudian belajar kepada hal-hal yang bersifat khusus. Teori ini mengasumsikan bahwa peserta didik belajar dengan baik apabila memahami prinsipprinsip yang bersifat umum, belajar secara deduktif dari aturan-aturan atau prinsip prinsip sampai pada contoh-contoh. Proses pembelajaran yang bermakna (meaning full learning) yang dikembangkan oleh Ausubel menekankan pada interaksi verbal yang dinamis antara pendidik dengan peserta didik. Pendidik memulai dengan suatu advance organizer (pemandu awal), kemudian ke sub-sub pembahasan dalam materi yang diajarkan, selanjutnya dikembangkan langkah-langkah yang dapat diimplementasikan seorang pendidik dalam proses pembelajarannya dengan strategi ekspositori.

\section{Konsep Dasar Strategi Pembelajaran}

\section{Makna Strategi}

Secara etimologi, strategi berasal dari bahasa Yunani yaitu "strategos" yang memiliki makna, yaitu; suatu usaha untuk mencapai suatu kemenangan dalam suatu peperangan. Pada awalnya kata strategi digunakan dalam lingkungan militer namun istilah strategi digunakan dalam berbagai bidang yang memiliki esensi yang relatif sama termasuk diadopsi dalam konteks pembelajaran yang dikenal dalam istilah strategi pembelajaran. ${ }^{5}$ Sedang dalam Kamus Besar Bahasa Indonesia Online, strategi memiliki beberapa arti, yaitu; (a) ilmu dan seni menggunakan semua sumber daya bangsa (bangsa) untuk melaksanakan kebijaksanaan tertentu dalam perang dan damai; (b) ilmu dan seni memimpin bala tentara untuk menghadapi musuh dalam perang; (c) rencana yang cermat mengenai kegiatan untuk mencapai sasaran khusus. ${ }^{6}$

Strategi merupakan usaha untuk memperoleh kesuksesan dan keberhasilan dalam mencapai tujuan. Dalam dunia pendidikan strategi dapat diartikan sebagai a plan,

\footnotetext{
${ }^{5}$ Masitoh \& Laksmi Dewi, Strategi Pembelajaran, (Jakarta: DEPAG RI, 2009),. 37.

${ }^{6}$ https://kbbi.web.id/strategi, diakses pada tanggal, 1 Mei 2018.
} 
method, or series of activities designed to achieves a particular educational goal. ${ }^{7}$ Strategi pembelajaran dapat diartikan sebagai perencanaan yang berisi tentang rangkaian kegiatan yang didesain untuk mencapai tujuan pendidikan tertentu. Strategi pembelajaran merupakan rencana tindakan (rangkaian kegiatan) termasuk penggunaan metode dan pemanfaatan berbagai sumber daya atau kekuatan dalam pembelajaran yang disusun untuk mencapai tujuan tertenu. Dalam hal ini adalah tujuan pembelajaran.

Selanjutnya, Djamarah dalam Riyanto menjelaskan sebagai berikut;

"Bahwa secara umum strategi mempunyai pengertian suatu garis-garis besar haluan untuk bertindak dalam usaha mencapai sasaran yang telah ditentukan. Berkaitan dengan pembelajaran, strategi dapat diartikan sebagai pola-pola umum kegiatan pendidik dengan anak didik dalam perwujudan kegiatan pembelajaran untuk mencapai tujuan yang telah digariskan". 8

Senada hal tersebut, Dick dan Carey menjelaskan bahwa strategi pembelajaran adalah semua komponen materi/paket pengajaran dan prosedur yang digunakan untuk membantu peserta didik dalam mencapai tujuan pengajaran. Secara operasional pengertian strategi pembelajaran dapat dipahami tentang pertanyaan-pertanyaan yang terkait dengan strategi pembelajaran sebgaimana yang telah dirumuskan Slameto dalam Riyanto, bahwa strategi pembelajaran mencakup jawaban atas pertanyaan :

a. Siapa melakukan apa dan menggunakan alat apa dalam proses pembelajaran. Kegiatan ini menyangkut peranan sumber, penggunaan bahan, dan alat-alat bantu pembelajaran.

b. Bagaimana melaksanakan tugas pembelajaran yang telah memberikan hasil yang optimal. Kegiatan ini menyangkut metode dan teknik pembelajaran.

c. Kapan dan di mana kegiatan pembelajaran dilaksanakan serta berapa lama kegiatan tersebut dilaksanakan didefinisikan (hasil analisis) sehingga tugas tersebut dapat dilaksanakan. ${ }^{9}$

Kemudian senada hal tersebut, Twelker mengemukakan bahwa pada dasarnya strategi pembelajaran mencakup empat hal, yaitu : (1) Penetapan tujuan pengajaran, (2) Penetapan sistem pendekatan pembelajaran, (3) Pemilihan dan penetapan metode,

\footnotetext{
${ }^{7}$ J. R. David dalam Pengawas, Strategi Pembelajaran dan Pemilihannya (Jakarta: Direktorat Jenderal Tenaga Kependidikan Nasional, 2008), . 6.

${ }^{8}$ Yatim Riyanto, Paradigma Baru Pembelajaran: Sebagai Referensi bagi Pendidik/Pendidik dalam Implementasi Pembelajaran yang Efektif dan Berkualitas (Jakarta: Kencana, 2010), . 131

${ }^{9}$ Yatim Riyanto, Paradigma Baru...,. 132.
} 
Muhammad Tang, Pengembangan Strategi Pembelajaran Pendidikan Agama Islam (PAI) dalam Merespon Era Digital

teknik dan prosedur pembelajaran. Termasuk penetapan alat, media, sumber dan fasilitas pengajaran serta penetapan langkah-langkah strategi pembelajaran (kegiatan pembelajaran dan pengelolaan waktu), (4) Penetapan kriteria keberhasilan proses pembelajaran dari dan dengan evaluasi yang digunakan. ${ }^{10}$

Dari berbagai perspektif tersebut, bahwa strategi pembelajaran dapat dideskripsikan suatu rancangan atau rencana yang disusun oleh pendidik untuk mencapai tujuan pembelajaran. Untuk mencapai atau menjalankan rencana tersebut dibutuhkan suatu metode, yang disebut dengan metode pembelajaran. Sedang untuk mengimplementasikan suatu metode pembelajaran dibutuhkan tehnik pembelajaran. Seorang pendidik yang melaksanakan tehnik pembelajaran memiliki gaya pembelajaran masing-masing. Misalnya, ada pendidik memiliki gaya humoris; dan ada pula pendidik memiliki gaya serius tapi santai dan ada juga pendidik memiliki gaya serius dari awal pembelajaran sampai akhir pembelajaran. Dalam memandang atau sudut pandang pendidik terhadap proses pembelajaran disebut dengan pendekatan pembelajaran.

\section{Komponen Strategi Pembelajaran}

Dick dan Carey, menyebutkan bahwa terdapat 5 komponen strategi pembelajaran, yaitu (a) kegiatan pembelajaran pendahuluan, (b) penyampaian informasi, (c) partisipasi peserta didik, (d) tes, dan (e) kegiatan lanjutan. ${ }^{11}$ Sedang Bambang Warsita menyebutkan dengan mengelompokan strategi pembelajaran menjadi lima komponen yaitu (a) urutan kegiatan pembelajaran; (b) metode pembelajaran; (c) media yang digunakan; (d) waktu tatap muka; (e) pengelolaan kelas.

Untuk memahami secara luas dan mendalam komponen-komponen tersebut, maka penulis akan mengembangkan dalam uraian berikut ini.

Pertama, kegiatan pembelajaran pendahuluan; pada kegiatan awal pembelajaran agar dapat berjalan dengan baik dan peserta didik dapat termotivasi dalam pembelajaran, maka ada beberapa hal yang harus dilakukan, diantaranya; (a) memastikan kelas tertata rapi dan bersih, (b) mengatur posisi peserta didik, (c) memberikan apersepsi dan motivasi kepada peserta didik dengan menyampaikan tujuan yang akan dicapai dalam pembelajaran tersebut, (d) membangun kerangka pikir peserta

\footnotetext{
${ }^{10}$ Yatim Riyanto, Paradigma Baru...,134.

${ }^{11}$ Dick Walter \& Carey Lou, The Systematic Desgn of Instruction (New York: Harper Collins publishers, 1994), 3.
} 
didik tentang materi yang akan dipelajari dengan menyampaikan pokok-pokok materi pada setiap sub bab dan keterkaitan pokok-pokok materi tersebut.

Kedua, menyampaikan informasi; tehnik penyampaian informasi (materi) kepada peserta didik harus menggunakan bahasa yang mudah dipahami dan tidak bertele-tele. Sehingga apa yang disampaikan mudah dicerna dan dipahami oleh peserta didik. Sedangkan hal-hal yang perlu disampaikan pada saat pembelajaran adalah hal-hal pokok materi yang diajarkan, serta tujuan dan manfaat materi tersebut baik yang bersifat subtantif maupun yang bersifat pragmatis untuk peserta didik dan masyarakat umum lainnya.

Ketiga, partisipasi peserta didik; dalam paradigma pendidikan sekarang ini, bahwa peserta didik harus menjadi pusat pembelajaran atau dengan istilah student centred learning (SCL), sedang pendidik hanya menjadi pasilitator dalam pembelajaran. Untuk membangun paradigma tersebut, para ahli melahirkan atau merumuskan strategi pembelajaran yang berpusat kepada peserta didik. Misalnya, strategi pembelajaran coverative learning, active learning, atau dengan istilah yang kita kenal Cara Belajar Peserta didik Aktif (CBSA).

Keempat, tes; untuk mengetahui materi yang disampaikan atau diinformasikan kapada peserta didik paham atau tidak, maka harus dilakukan tes atau evaluasi. Tes atau evaluasi merupakan salah satu komponen yang sangat penting dalam proses pembelajaran. Oleh karena, dengan adanya tes atau evaluasi seorang peserta didik akan mengetahui tingkat kemampuannya; seorang pendidik akan memahami tepat atau tidak strategi dan metode yang digunakan. Akan tetapi, hal yang kurang dilakukan oleh pendidik adalah refleksi terhadap strategi dan metode yang digunakan dalam pembelajaran. Sehingga apabila terjadi kagagalan atau kurang berhasilnya pembelajaran dilimpahkan kepada peserta didik. Pada hal berhasil atau tidaknya pembelajaran sangat ditentukan oleh pendidik itu sendiri. Tentunya, tidak menapikan komponen-komponen lainnya.

Kelima, kegiatan lanjutan; dalam kegiatan lanjutan ini setelah tes, hal yang perlu dilakukan adalah setelah diperiksa hasil tes peserta didik; bagi peserta didik yang tidak tuntas akan diadakan remedial setelah diberikan pengayaan terhadap kompetensi dasar (KD) yang belum dipahami atau belum tuntas. Sedang bagi peserta didik yang sudah tuntas (mencapai KKM) juga diberikan pengayaan yang bersifat pengembangan. 
Muhammad Tang, Pengembangan Strategi Pembelajaran Pendidikan Agama Islam (PAI) dalam Merespon Era Digital

Kemudian komponen yang penting selain yang disebutkan di atas adalah pendidik yang bersifat inovatif dan kreatif dalam merancang dan menyusun strategi pembelajaran. Pendidik yang inovatif dan kreatif dalam merancang dan menyusun strategi pembelajaran akan merespon tingkat perkembangan peserta didik, termasuk memperhatikan realitas kehidupan masyarakat sekarang ini. Masyarakat sekarang ini, khususnya peserta didik sangat akrab dengan alat digital, seperti; Hand Phone Smart, Laptop, dan alat digital lainnya. Untuk itu, seorang pendidik harus merespon realitas kehidupan masyarakat atau peserta didik dengan merancang dan menyusun strategi pembelajaran berbasis digital. Dengan menyelami kondisi atau keadaan peserta didik, dan akan memberikan sesuai dengan bakat dan minatnya; maka mendorong motivasi peserta didik untuk mengikuti secara sungguh-sungguh atau serius proses pembelajaran.

\section{Klasifikasi Strategi Pembelajaran}

Sanjaya dalam Eka terdapat beberapa strategi pembelajaran yang dianjurkan untuk diimplementasikan oleh seorang pendidik, yaitu; (a) Strategi pembelajaran yang bertujuan untuk meningkatkan aspek kognitif (berpikir), (b) Strategi pembelajaran kooperatif, (c) Strategi pembelajaran afektif. ${ }^{12}$

Berikut ini, akan dijelaskan ketiga klasifikasi strategi pembelajaran tersebut yaitu; pertama, Strategi pembelajaran yang bertujuan untuk meningkatkan kemampuan berpikir merupakan strategi pembelajaran yang menekankan kepada kemampuan berpikir peserta didik. Strategi pembelajaran ini materi pelajaran tidak disajikan begitu saja kepada peserta didik, akan tetapi peserta didik dibimbing untuk proses menemukan sendiri konsep yang harus dikuasai melalui proses dialogis yang terus menerus dengan memanfaatkan pengalaman peserta didik. Model strategi pembelajaran peningkatan kemampuan berpikir adalah model pembelajaran yang bertumpu kepada pengembangan kemampuan berpikir peserta didik melalui telaahan fakta-fakta atau pengalaman anak sebagai bahan untuk memecahkan masalah yang diajarkan.

Kedua, strategi pembelajaran kooperatif; Model pembelajaran kelompok adalah rangkaian kegiatan belajar yang dilakukan oleh peserta didik dalam kelompokkelompok tertentu untuk mencapai tujuan pembelajaran yang telah dirumuskan. Ada empat unsur penting dalam strategi pembelajaran kooperatif yaitu: (a) adanya peserta

\footnotetext{
${ }^{12}$ Eka Elprida, Strategi Pembelajaran, Jurnal Pendidikan, Universitas Pendidikan Indonesia, 2015, 2.
} 
dalam kelompok, (b) adanya aturan kelompok, (c) adanya upaya belajar setiap kelompok, dan (d) adanya tujuan yang harus dicapai dalam kelompok belajar.

Ketiga, Strategi pembelajaran afektif memiliki perbedaan dengan strategi pembelajaran kognitif dan keterampilan (skill). Afektif berhubungan dengan nilai (value), yang sulit diukur, oleh sebab itu menyangkut kesadaran seseorang yang tumbuh dari dalam diri peserta didik. Dalam batas tertentu memang afeksi dapat muncul dalam kejadian behavioral, akan tetapi penilaiannya untuk sampai pada kesimpulan yang bisa dipertanggung jawabkan membutuhkan ketelitian dan observasi yang terus menerus, dan hal ini tidaklah mudah untuk dilakukan

Setelah melihat konsep dasar strategi pembelajaran tersebut, baik dilihat dari segi pengertian, komponen, dan klasifikasinya dapat memberikan gambaran bahwa mengembangkan strategi pembelajaran sangat urgen dalam dunia pendidikan. Kurang tepatnya atau gagalnya strategi yang diimplementasikan dalam proses pembelajaran berakibat gagalnya untuk mencapai tujuan pendidikan. Sama halnya, kalah strategi dalam peperangan bisa berakibat fatal; kemenagan yang didambakan-kekalahan yang diraih. Atau dalam permainan sepak bola, pelatih senantiasa mengatur strategi pemainnya agar dapat menang dalam permainan tersebut.

Kemudian strategi pembelajaran Pendidikan Agama Islam (PAI) yang dimaksud dalam tulisan ini adalah strategi pembelajaran yang diimplementasikan dalam proses pembelajaran pada mata pelajaran Pendidikan Agama Islam (PAI) baik ditingkat sekolah, maupun ditingkat madrasah atau pesantren (diniyah). Walaupun istilah Pendidikan Agama Islam (PAI) di madrasah/pesantren (diniyah) disebut dengan pendidikan keagamaan Islam. Hal ini sesuai dengan Peranturan Pemerintah (PP) Nomor 55 Tahun 2007.

\section{Langkah-Langkah Strategis untuk Mengembangkan Strategi Pembelajaran PAI dalam Merespon Era Digital}

\section{Mengubah Paradigma}

Langkah awal yang harus dilakukan dalam mengembangkan strategi pembelajaran PAI adalah mengubah paradigma atau cara pandang kita terhadap pembelajaran PAI itu sendiri. Oleh karena paradigma merupakan landasan ke mana arah dan tujuan pembelajaran itu. Pada sebagian atau bahkan secara umum pendidik PAI sekarang ini, paradigma yang dikembangkan adalah paradigma tekstual yang stagnan 
Muhammad Tang, Pengembangan Strategi Pembelajaran Pendidikan Agama Islam (PAI) dalam Merespon Era Digital

pada normatif tanpa mengkaji secara kontekstual (apa yang menjadi kebutuhan peserta didik dalam menghadapi kehidupannya kelak setelah tamat). Sehingga pembelajaran PAI di sekolah/madrasah kurang bermakna pada peserta didik. Bahkan terkesan hanya mementingkan pada nilai kognitifnya sehingga peserta didik tersebut dapat lulus dalam ujian.

Senada hal tersebut, Musa Asy'arie menjelaskan berikut ini;

"bahwa pendidikan sekolah kita seharusnya dikembalikan kepada realitas dinamika masyarakatnya, bukan menjadi menara gading yang tercabut dari akar kehidupan masyarakatnya sendiri. Pendidikan sekolah bukan untuk mengajarkan mimpi dan anti realitas, tetapi menjadi bagian yang sah dari realitas hidup masyarakatnya sendiri untuk mencari jawab atas proses dialektika yang terus bergolak dalam kehidupan masyarakatnya". ${ }^{13}$

Uaraian Musa Asy'arie ini terkait pendidikan secara umum, akan tetapi itu juga yang terjadi pada PAI; baik dari segi materinya maupun dari segi pengembangan strategi pembelajaran. Dalam era digital sekarang ini, perlu membangun paradigma atau pendekatan secara kontekstual (mengkaji dalil-dalil syar'i sebagai sumber materi PAI sesuai dengan tuntutan zaman/realiatas masyarakat) dan integratif (keterpaduan nilai sains dan teknologi dan nilai-nilai iman dan taqwa/ IPTEK dan IMTAQ) dalam mengembangkan strategi pembelajaran PAI. Di samping itu, kita jangan hanya terjebak pada dalil syar'i yang bersifat qauliyah (terucap dalam al-Qur'an) sebagai sumber materi PAI, akan tetapi perlu mengkaji dalil yang bersifat kauniyah (tercipta/gejala alam) menjadi pedoman dalam pengembangan materi PAI. Zaman sekarang ini, menuntut kita untuk menguasai sains dan teknologi, informasi dan komunikasi, dan alat teknologi lainnya.

Untuk mengaktualisasikan konsep tersebut, penulis mencoba merumuskan kerangka pikir pengembangan strategi pembelajaran PAI yang bersifat integratif sebagaimana telah dijelaskan di atas. Adapun konsep atau kerangka pikir yang dimaksud dapat dilihat pada bagan berikut ini:

${ }^{13}$ Musa Asy’arie, NKRI,.... 190. 


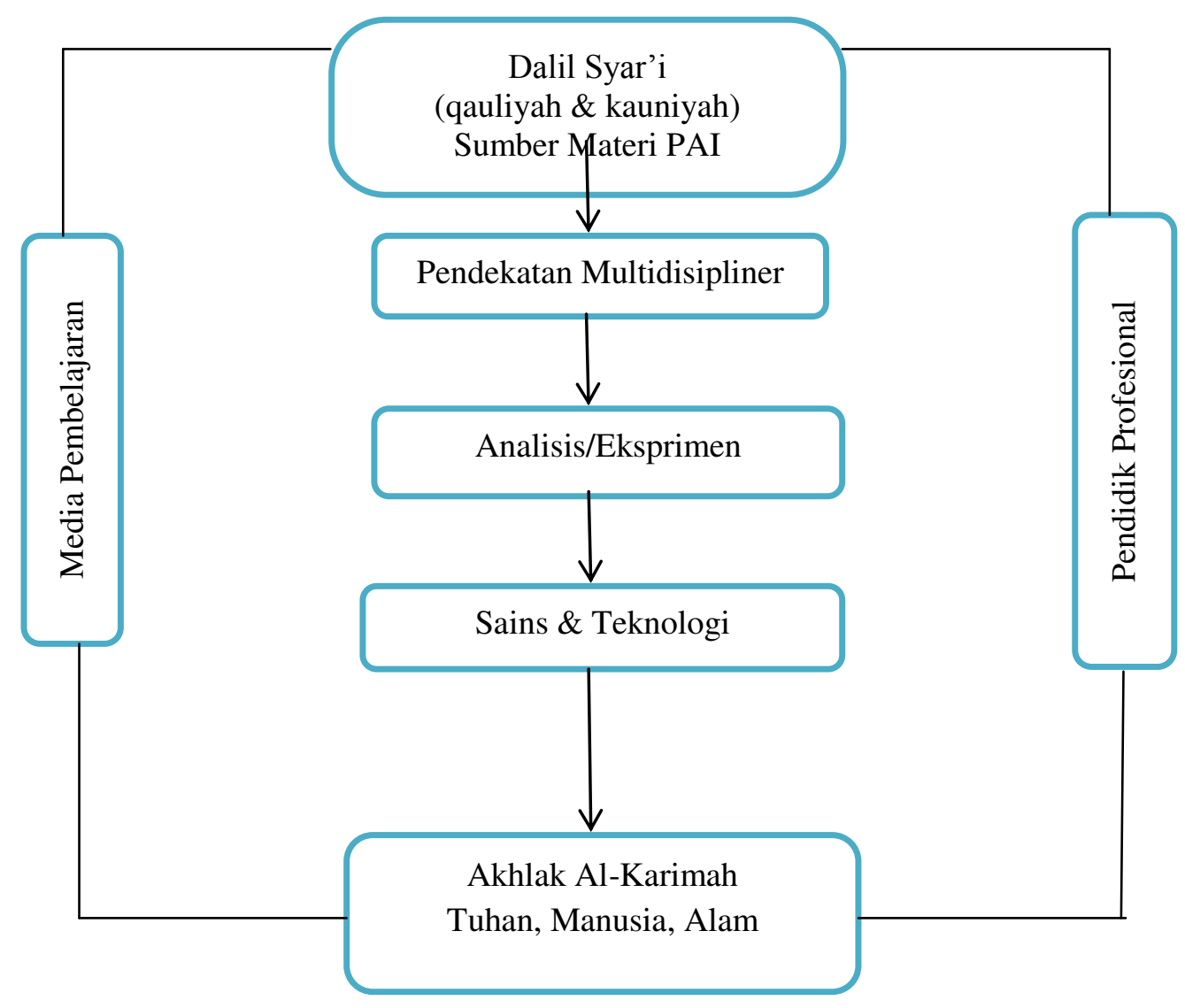

Strategi Pembelajaran PAI Terpadu (IMTAQ \& IPTEK)

Adapun maksud bagan tersebut adalah, yaitu:

Pertama, bahwa yang dijadikan sumber materi PAI adalah dalil syar'i yang bersifat qauliyah (terucap) dan qauniyah (tercipta) atau lingkungan sekitar. Kedua, dalil yang bersifat qauliyah harus diinterpretasikan/ditafsirkan dengan pendekatan multidisipliner (berbagai displin ilmu). Sedang dalil yang bersifat kauniyah (gejala alam/realitas kehidupan) juga harus dijadikan dasar dalam mengembangkan materi PAI agar dapat memberikan solusi dalam setiap lini kehidupan manusia.

Ketiga, dari pemahaman secara kontekstual-multidisipliner dianalisis (bagi dalildalil yang membutuhkan analisis yang tajam dan mendalam), dan materi yang bersifat kauniyah membutuhkan observasi dan eksprimen sehingga dapat menghsilkan nilai sains dan teknologi, dan/ atau membuktikan seacara ilmiah apa yang kita paham dan yakini. Dalil-dalil qauliyah tidak hanya dipahami secara tekstual (lapdziyah)akan tetapi dengan pendekatan kontekstual-multidisipliner keyakinan kita akan semakin mendalam dan kuat karena dilandasi dengan rasionalitas (dapat dibuktikan secara ilmiah). 
Muhammad Tang, Pengembangan Strategi Pembelajaran Pendidikan Agama Islam (PAI) dalam Merespon Era Digital

Keempat, dengan terinternalisasinya dalam diri keyakinan yang didasari atas kebenaran secara ilmiah/rasional (bukan taklid buta) merupakan landasan lahirnya kepribadian yang kokoh (berkualitas) dan luhur (akhlak karimah). Inilah yang menjadi inti/hakikat dari tujuan Pendidikan Agama Islam (PAI), yakni melahirkan manusia insan kamil (manusia yang memiliki kepribadian yang tangguh (berkualitas \& professional) dan luhur (moralitas yang tinggi/akhlak karimah)

Kelima, untuk mengaplikasikan strategi pembelajaran ini dibutuhkan pendidik yang berkuliatas dan professional, serta didukung dengan media pembelajaran yang yang memenuhi standar pembelajaran.

\section{Meningkatkan Profesionalisme Pendidik Pendidikan Agama Islam (PAI)}

Pendidik merupakan gerbong terpenting dalam perubahan dunia pendidikan; maka untuk itu pendidik harus mendapat perhatian yang maksimal. Sehingga dapat menjadi pendidik profesional, untuk meningkatkan keprofesionalan pendidik PAI dalam melaksanakan strategi pembelajaran, yang harus dilakukan adalah memberikan pembinaan; baik yang bersifat jangka pendek (pelatihan, diklat dan lain-lain) dan yang berifat jangka panjang (memberikan kesempatan/beapeserta didik) untuk meningkatkan studinya (dari S1 ke S2/magister, atau kalau memungkinkan sampai S3/doktor).

Sedang menurut Wina Sanjaya bahwa strategi pencapaian proses pendidikan melalui peningkatan dan perbaikan dilihat dari sudut pendidik yang meliputi tentang peningkatan profesional pendidik serta mengoptimalkan peran pendidik dalam proses pembelajaran. $^{14}$

Pertama, meningkatkan profesional pendidik; meyakinkan kepada setiap orang khususnya kepada pendidik bahwa pekerjaannya merupakan pekerjaan profesional. Sehingga seorang pendidik tidak hanya sekedar mengajar (transfer of knowlege), tapi seorang pendidik harus bertindak sebagai pendidik dan pembimbing peserta didik agar tercapai tujuan pendidikan. Seorang pendidik perlu memiliki kemampuan merancang dan meingimplementasikan berbagai strategi pembelajaran yang dianggap cocok dengan minat dan bakat serta sesuai dengan taraf perkembangan peserta didik termasuk di dalamnya memanfaatkan berbagai sumber dan media pembelajaran untuk menjamin efektivitas pembelajaran.

\footnotetext{
${ }^{14}$ Wina Sanjaya, Kurikulum dan Pembelajaran: Teori dan Praktik Pengembangan Kurikulum Tingkat Satuan Pendidikan (KTSP) (Jakarta: Kencana, 2008), . 273.
} 
Untuk meyakinkan bahwa pendidik sebagai pekerjaan profesional mari kita tinjau syarat-syarat atau ciri pokok dari pekerjaan profesional. Pertama, pekerjaan profesional ditunjang oleh suatu ilmu tertentu secara mendalam yang hanya mungkin didapatkan dari lembaga-lembaga pendidikan yang sesuai, sehingga kinerjanya didasarkan kepada keilmuan yang dimilikinya yang dapat dipertanggungjawabkan secara ilmiah. Kedua, suatu profesi menekankan kepada suatu keahllian dalam bidang tertentu dalam bidang tertentu yang spesifik sesuai dengan profesinya, sehingga antara profesi yang satu dengan yang lainnya dapat dipisahkan secara tegas. Ketiga, tingkat kemampuan dan keahlian suatu profesi didasarkan kepada latar belakang pendidikan yang dialaminya yang diakui oleh masyarakat. Suatu profesi selain dibutuhkan oleh masyarakat juga memiliki dampak terhadap sosial kemasyarakatan, sehingga masyarakat memiliki kepekaan yang sangat tinggi terhadap setiap efek yang ditimbulkannya dari pekerjaan profesi itu. ${ }^{15}$

Nanah Syaodih Sukmadinata menjelaskan hasil diskusi pengembangan model pendidikan profesional tenaga pendidikan yang diselenggarakan oleh PPS IKIP Bandung tahun 1990, dirumuskan 10 ciri suatu profesi yaitu; (a) Memiliki fungsi dan signifikansi sosial, (b) Memiliki keahlian/keterampilan tertentu, keahlian/keterampilan diperoleh dengan menggunakan teori dan metode ilmiah, (d) Didasarkan atas disiplin ilmu yang jelas, (e) Diperoleh dengan pendidikan dalam masa tertentu yang cukup lama, (f) Aplilaksi dan sosialisasi nilai-nilai profesional, (g) Memiliki kode etik, (h) Kebebasan untuk memberikan judgment dalam memecahkan masalah dalam lingkungan kerjanya, (i) Memiliki tanggung jawab profesional dan otonomi, (j) Ada pengakuan dari masyarakat dan imbalan atas layanan profesinya. ${ }^{16}$

Menurut Tilaar, para profesional mempunyai ciri-ciri yang khusus. Mereka mengabdi pada suatu profesi. Adapun ciri-ciri dari suatu profesi, yaitu: (a) Memiliki suatu keahlian khusus, (b) Merupakan suatu panggilan hidup, (c) Memiliki teori-teori yang baku secara universal, (d) Mengabdikan diri untuk masyarakat dan bukan untuk diri sendiri, (e) Dilengkapi dengan kecakapan diagnostik dan kompetensi yang aplikatif, (f) Memiliki otonomi dalam melaksanakan pekerjaannya, (g) Mempunyai kode etik, (g)

\footnotetext{
${ }^{15}$ Wina Sanjaya, Kurikulum dan..., 275.

${ }^{16}$ Nanah Syaodih Sukmadinata, Pengembangan...,. 191.
} 
Muhammad Tang, Pengembangan Strategi Pembelajaran Pendidikan Agama Islam (PAI) dalam Merespon Era Digital

Mempunyai klien yang jelas, (h) Mempunyai organisasi profesi yang kuat, (j) Mempunyai hubungan dengan profesi pada bidang-bidang yang lain. ${ }^{17}$

Dari pandangan beberapa ahli tersebut, tentang karakter khusus atau ciri-ciri suatu profesi memberikan suatu gambaran bahwa suatu profesi membutuhkan suatu kompetensi dan skill (keterampilan) yang berlandaskan kepada teori ilmiah, kode etik (moral, religius/agama, dan hukum) yang dapat dipertanggungjawabkan. Tentunya, kaidah-kaidah ini juga berlaku pada profesi pendidik dan dosen; karena, pendidik dan dosen merupakan suatu profesi.

Kedua, optimalisasi peran pendidik; teori lama menjelaskan bahwa peran pendidik hanya meyampaikan atau mewariskan ilmu penghetahuan sebagai warisan budaya masa lalu yang dianggap bermanfaat untuk dilestarikan. Sehingga lahir paradigma bahwa pendidik adalah pusat atau satu-satunya sumber ilmu pengetahuan (learning resources) dalam proses pembelajaran. Dalam konteks seekarang ini, zaman sudah berubah dan paradigma pendidikan telah berubah bahwa peserta didik atau peserta didik adalah pusat pembelajaran (student centred learning). Sehingga fungsi dan peran pendidik pun berubah; sebelumnya satu-satunya sumber ilmu pengetahuan dalam pembelajaran sekarang ini pendidik bertindak sebagai pasilitator dalam pembelajaran. Mengarahkan dan membimbing peserta didik agar dapat lebih aktif dalam proses pembelajaran.

Sebagai pendidik profesional, bukan hanya dituntut melaksanakan tugasnya secara profesional, tetapi juga harus memiliki pengetahuan dalam kemampuan profesional. Louis E. Raths dalam Nanah Syaodih Sukmadinata, mengemukakan sejumlah kemampuan yang harus dimiliki oleh seorang pendidik, yaitu; (a) Expalining, informing, showing how, (b) Intiating, directing, administering, (c) Unifying the group, (d) Giving security, (e) Clarifying, attitudes, beliefs, problems, (f) Making curriculum materials, (g)Evaluating, recording, reporting, (h) Enriching community activates, $(i)$ organizing and arranging classroom, (j) Participating in school activities, ( $k$ ) Patcipating in professional an civic life. ${ }^{18}$

\footnotetext{
17 H. A. R. Tilaar, Paradigma Baru Pendidikan Nasional, (Jakarta: Rineka Cipta, 2000). 137.

${ }^{18}$ Nanah Syaodih Sukmadinata, Pengembangan Kurikulum Teori dan Praktik (Cet. XIX; Bandung: PT Remaja Rosda Karya, 2016), . 192.
} 
Peraturan Pemerintah (PP) Nomor 14 Tahun 2005, tentang Pendidik dan Dosen, pada BAB III pasal 7 ayat 1; Profesi pendidik dan profesi dosen merupakan bidang pekerjaan khusus yang dilaksanakan berdasarkan prinsip sebagai berikut:

a. Memiliki bakat, minat, panggilan jiwa, dan idealisme;

b. Memiliki komitmen untuk meningkatkan mutu pendidikan, keimanan, ketakwaan, dan akhlak mulia;

c. Kualifikasi akademik dan latar belakang pendidikan sesuai dengan bidang tugas;

d. Memiliki kompetensi yang diperlukan. sesuai dengan bidang tugas;

e. Memiliki tanggung jawab atas pelaksanaan tugas keprofesionalan;

f. Memperoleh penghasilan yang ditentukan sesuai dengan prestasi kerja;

g. Memiliki kesempatan untuk mengembangkan keprofesionalan secara berkelanjutan dengan belajar sepanjang hayat;

h. Memiliki jaminan perlindungan hukum dalam melaksanakan tugas keprofesionalan; dan

i. Memiliki organisasi profesi yang mempunyai kewenangan mengatur hal-hal yang berkaitan dengan tugas keprofesionalan pendidik. ${ }^{19}$

Selanjutnya, dalam pasal 10 disebutkan bahwa; (1) Kompetensi pendidik sebagaimana dimaksud dalam Pasal 8 meliputi kompetensi pedagogik, kompetensi kepribadian, kompetensi sosial, dan kompetensi profesional yang diperoleh melalui pendidikan profesi. $^{20}$

Apa yang telah ditetapkan pemerintah tersebut, merupakan suatu standar minimal yang harus dimiliki seorang pendidik atau dosen. Dalam merespon perkembanggan sekarang ini, kemajuan ilmu pengetahuan dan teknologi informasi dan komunikasi yang biasa disebut era revolusi 4.0 (era digitalisasi industri), maka peran dan fungsi pendidik PAI harus dioptimalkan; yang sebelumnya "gaptek", maka sekarang ini harus ditingkatkan kompetensi dan skill-nya untuk dapat mempergunakan alat digital dalam proses pembelajaran. Hal ini menjadi tuntutan, karena realitas masyarakat khususnya peserta didik mereka sangat akrab dengan alat digital. Tentunya,

\footnotetext{
${ }^{19}$ Peraturan Pemerintah (PP) Nomor 14 Tahun 2005, tentang Pendidik dan Dosen, pada BAB III pasal 7 ayat 1.

${ }^{20}$ Peraturan Pemerintah (PP) Nomor 14 Tahun 2005, tentang Pendidik dan Dosen, pada BAB IV pasal 10 ayat 1.
} 
Muhammad Tang, Pengembangan Strategi Pembelajaran Pendidikan Agama Islam (PAI) dalam Merespon Era Digital

dengan merespon keadaan ini diharapkan dapat menumbuhkan minat dan motivasinya dalam belajar.

\section{Mengembangkan Materi PAI sessuai dengan Realitas Kebutuhan Masyarakat/Umat}

Untuk mengembangkan strategi pembelajaran PAI, maka salah satu langkah yang harus dilakukan adalah mengembangkan materi PAI sesuai dengan realitas kebutuhan masyarakat/umat. Namun realitasnya, pengembangan materi PAI di lembaga pendidikan umum/agama(pesantren) apabila dilihat dari segi karakterisiknya cenderung yang ditonjolkan masalah-masalah berikut ini:

Pertama, pengembangan materi PAI sebatas religios sciences atau teo-sentris semata. Atau dengan kata lain, pembelajaran PAI di sekolah/madrasah stagnan pada aspek spiritual/ukhrawi saja, tanpa mengkaji semangat/hikmah yang terkandung dalam ibadah/syariat tersebut. Pada hal setiap ibadah atau syariat yang diturunkan Allah SWT., untuk umat manusia memiliki dua manfaat, yaitu manfaat yang dapat dirasakan di dunia dan manfaat yang dapat diraih diakhirat. Misalnya, dalam materi ibadah Haji dan Umrah; yang diajarkan adalah sebatas tata cara pelaksanaannya (rukun dan syaratnya); seharusnya, kita perlu mengkaji ibadah haji dari aspek wasail-nya; hal ini dapat dilihat dalam qawaid al fiqhiyah disebutkan: "Memerintahkan/mewajibkan sesuatu, maka segala yang berkaitan dengannya menjadi wajib pula”. Dalam hal ini, wasail Ibadah Haji dan Umrah dari aspek ekonomi adalah bahwa seoang muslim diperlukan kerja keras untuk memiliki kemampuan secara finansial; dari aspek sains dan teknologi (IPTEK), bahwa seorang muslim harus memiliki kemampuan untuk menciptakan alat transfortasi (pesawat terbang); jangan hanya sebagai komsumen/pemakai, tetapi kita harus menjadi produsen/pencipta. Tetapi ironisnya, umat Islam sekarang ini puas dengan menyandang predikat "komsumen".

Senada hal tersebut di atas, Amin Abdullah dalam pandangannya tentang posisi PAI secara intelektual dan institusional, dalam posisi "terisolasi" dari dinamika perkembangan dunia yang lebih luas. Dengan kata lain, selama ini dunia pendidikan Islam masih selalu bergerak dalam persfektif "inword looking" (berorientasi ke dalam) tidak banyak upaya pengembangan keluar karena masik sibuk menpendidiksi diri 
sendiri. Maka tidak mengherankan bila yang terjadi adalah stagnasi. Dalam bahasa pesantren sering disebut sebagai "mabni" (tidak bisa berubah). ${ }^{21}$

Kedua, materi PAI yang dikembangkan di sekolah/madrasah lebih cenderung mengedepankan masalah fiqhiyah. Sehingga materi PAI cenderung bermadzhabbermadzhab atau terpola-pola. Misalnya, apabilah sekolah/madrasah/pesantren tersebut di bawah naungan Nahdatul Ulama (NU) maka materi PAI yang dikembangkan adalah madzhab NU. Begitupun sebaliknya, apabilah sekolah/madrasah/pesantren tersebut di bawah naungan Muhammadiyah maka materi PAI yang dikembangkan adalah madzhab Muhammadiyah dan madzhab lainnya. Apabila pengembangan materi PAI seperti ini akan melahirkan peserrta didik fanatisme madzhab yang tidak menerima madzhab lainnya. Bahkan dapat menjadi pemicu timbulnya konflik secara intern (umat Isam) maupn secara eksteren. Secara intern, antar madzhab (golongan/aliran) dengan madzhab lainnya, seperti apa yang terjadi antara madzhab Ahmadiyah dengan madzhab FPI. Sedang komplik secara ekstern telah banyak menelan korban nyawa anak manusia atas nama agama, seperti apa yang terjadi di Poso dan dia Ambon. Namun, walaupun demikian masih ada juga sekolah/madrasah/pesantren yang berusaha "netral" (mengembangkan materi PAI tidak cenderung kesatu Madzhab). Misalnya, Pesantren Modern Pendidikan Al-Qur'an IMMIM Putra Makassar yang mengambil motto “Bersatu dalam Aqidah Toleransi dalam Masalah Khilafiyah dan furu'iyah”. Dengan motto tersebut, Pesantren IMMIM berusaha untuk menyatukan umat; tidak menimbulkan perpecahan karena adanya perbedaan madzhab. Dalam pesantren ini, santri dibina dan dibimbing materi PAI untuk tidak cenderung hanya satu madzhab, tapi berusaha diperkenalkan beberapa madzhab agar tumbuh sikap toleransi dalam diri peserta didik (santri).

Kemudian, apabila dilihat dari aspek subtansi atau isi PAI yang dikembangkan sekarang ini belum merespon masalah-masalah yang dihadapi umat dan masalah manusia pada umumnya. Misalnya, umat Islam dihadapkan pada masalah kemiskinan dan keterpurukan ekonomi dibandingkan dengan umat lainnya. Begitupun juga umat Islam ketinggalan dari penguasaan sains dan teknologi (IPTEK).

\footnotetext{
${ }^{21}$ Amin Abdullah (Pengantar), dalam Imam Machali at al, Pendidikan Islam dan Tantangan Globalisasi: Buah Pikiran Seputar; Filsafat, Politik, Ekonomi, Sosial dan Budaya (Yogyakarta: PRESMA UIN Sunan Kalijaga, 2004), hal. X.
} 
Muhammad Tang, Pengembangan Strategi Pembelajaran Pendidikan Agama Islam (PAI) dalam Merespon Era Digital

Selanjutnya, hal lain yang perlu diperhatikan dalam pengembangan materi PAI adalah hendaknya lebih mengedepankan akhlak dibandingkan dengan masalah fiqhiyah. Oleh karena, akhlak adalah sesuatu yang bersifat universal dan dapat diterima oleh semua madzhab atau golongan. Bahkan akhlak dapat diterima di luar dari Islam itu sendiri. Dengan mengedepankan nilai-nilai akhlak pada materi PAI niscaya akan melahirkan peserta didik yang lebih humanis dan toleran terhadap orang-orang yang berbeda dengannya. Apakah perbedaan itu disebabkan karena pemikiran, aliran, ras, suku, agama dan bangsa akan dapat diterima menjadi satu makhluk Tuhan yang harus dihargai dan dihormati hak dan kewajibannya masing-masing.

\section{Inovatif dan Kreatif Mendesain Strategi dan Metode Pembelajaran}

Pendidikan agama Islam (PAI) dalam pelaksanaannya membutuhkan startegi dan metode yang tepat untuk menghantarkan kegiatan pendidikan kearah tujuan yang dicitacitakan. Bagimanapun baik dan sempurnanya suatu kurikulum pendidikan Islam, ia tidak akan berarti apa-apa, manakala tidak memiliki strategi dan metode atau cara yang tepat dalam mentranspormasikannya kepada peserta didik. Ketidaktepatan dalam penerapan metode secara praktis akan menghambat proses belajar mengajar yang akan berakibat membuang waktu dan tenaga secara percuma. Karenanya, strategi dan metode adalah syarat untuk efesiensinya aktivitas pembellajaran PAI. Hal ini berarti bahwa strategi dan metode termasuk persoalan yang esensial, karena tujuan pendidikan Islam itu akan tercapai secara tepat guna manakala jalan yang ditempuh menuju cita-cita tersebut benar dan tepat.

Dalam merancang dan merumuskan strategi dan metode pemelajaran di era digital sekarang ini ada beberapa hal yang harus diperhatikan oleh pendidik, kaitannya dengan implementasi strategi pembelajaran yang bersifat integratif dalam pembelajaran PAI yang dirangcang dalam tuisan ini, yaitu;

Pertama, isi materi dan tujuan akan dicapai; atau kompetensi dasar (KD) dan indikator yang akan dicapai. Misalnya, kita mengambil satu contoh materi dalam PAI tentang Makanan dan Minuman Haram Dalam Islam pada sub pembahasann Minuman Haram (miras). Pada strategi pembelajaran selama ini hanya bersifat normatif, misalnya; ketika kita bertanya kenapa minuman keras diharamkan? Jawabnya, karena ada dalilnya bahwa "segala minuman keras adalah memabukkan", dan "segala yang yang memabukkan adalah haram". Intinya, dalam membedah atau mengajarkan materi 
tersebut berhenti pada tahap normatif saja. Maka strategi yang dirancang dalam tulisan ini adalah tidak berhenti pada tahap normatif saja, akan tetapi lebih jauh mengeksplor bahwa kandungan apa yang terkandung dalam miras sehingga bisa menjadi haram? Maka untuk memahamkan kepada peserta didik tentang kandungan miras tersebut, peserta didik di bawah ke laboratorium untuk belajar. Tentunya, pembelajaran ini pendidik PAI harus kerja sama (membentuk team teaching) dengan pendidik kimia. Oleh karena, yang bisa mempraktekkan dan menjelaskan unsur-unsur yang terkandung dalam miras tersebut adalah pendidik kimia. Begitupun misalnya, kalau belajar tentang keharaman daging Babi dan darah; maka bisa dengan strategi dan metode seperti itu.

Kedua, membentuk team teaching; dalam membentuk team teaching ini harus dirancang jauh sebelum proses pembelajaran. Karena banyak hal yang harus disiapkan, terutama waktu pendidik yang kita ajak kerja sama dari bidang studi yang lain sesuai dengan konteks materi yang akan dipelajari. Kemudian persedian bahan dan jadwal penggunaan laboratorium perlu dikoordinasikan dengan pengelola lab.(laboran). Begitu juga jika kerja sama dengan pihak lain, misalnya; materi tentang Penentuan Awal dan Akhir Ramadan, maka tentu akan kerja sama dengan badan Hisab dan Rukyat Kementerian Agama RI.

\section{Melengkapi Media Pembelajaran}

Untuk mengembangkan strategi pembelajaran PAI, maka tidak terlepas pada sarana dan prasarana pendidikan atau media pembelajaran. Media pembelajaran merupakan salah satu unsur terpenting dalam menunjang proses pembelajaran. Keterbatasan sarana dan prasarana pendidikan dapat mengakibatkan tidak efektifnya proses pembelajaran.

Media pembelajaran ini, dimaksudkan sebagai alat bantu pembelajaran, dalam bentuk software multimedia interaktif. Media pembelajaran ini dimaksudkan untuk mempermudah peserta didik dalam mempelajari materi PAI. Materi media pembelajaran dikembangkan dan disesuaikan dengan silabus dan Rencana Pelaksanaan Pembelajaran (RPP). Perancangan dalam pembuatan media pembelajaran PAI berbasis powerpoint dan juga materi digital ini adalah: identifikasi tujuan, analisis, review kontruksional, merumuskan kompetensi dasar, dan mengembangkan kriteria. Dalam mengembangkan materi ajar dengan menggunakan powerpoint sebagai media presentasi membutuhkan kriteria keberhasilan pembelajan. Kriteria keberhasilan perlu 
Muhammad Tang, Pengembangan Strategi Pembelajaran Pendidikan Agama Islam (PAI) dalam Merespon Era Digital

dikembangkan sesuai dengan kompetensi dasar yang ada. Dimana kriteria tersebut merupakan bagian dari sub-sub kompetensi dasar, sehingga materi yang ada pada subsub kompetensi dasar dapat dikembangkan lebih dalam lagi.

Mengembangkan media pembelajaran secara digital dalam PAI merupakan suatu langkah strategis dalam merespon perkembangan zaman. Oleh karena, ada suatu mind set yang terbangun dalam diri peserta didik bahwa belajar PAI membosankan; hanya mendengarkan ceramah dan banyak menghapal. Sistem atau metode ceramah dan menghapal dalam pembelajaran PAI perlu dikemas atau dikembangkan agar lebih menarik dan lebih mudah untuk dicerna peserta didik. Tentunya, hal ini bisa dilakukan dengan sistem digital. Di zaman sekarang ini, seorang pendidik PAI tidak boleh "gaptek" (gagap teknologi) dalam melaksanakan proses pembelajaran.

Selanjutnya, yang perlu diperhatikan sekarang ini bahwa pendidik-pendidik PAI yang mengajar di sekolah; baik tingkat SD/MI, SMP/MTs, dan SMA/SMK/MA khususnya di sekolah negeri memiiliki umur yang menjelang pensiun (tua). Sehingga dengan kondisi seperti itu, mereka susah menyesuaikan diri dengan alat teknologi/digital. Bahkan sebagaian mereka tidak bersemangat lagi meningkatkan potensinya untuk mengembangkan strategi dan metode pembelajaran dengan sistem digital. Disinilah peran sekolah/madrasah, khususnya kepala sekolah bagaimana langkah-langkah dan pendekatannya terhadap masalah tersebut.

\section{Penutup}

Setelah mengkaji dan mendeskripsikan konsep dasar pengembangan strategi pembelajaran, maka dirimuskan suatu model pengembangan strategi pembelajaran yang dapat merespon perkembangan masyarakat di era digital atau biasa disebut era revolusi 4.0 (digitalisasi industri). Mind set atau pola pikir yang terbangun dalam masyarakat bahwa pembelajaran PAI bersifat konvensional dan tradisional yang membuat peserta didik tidak termotivasi dalam belajar; menganggap bahwa pendidik PAI telah gagal dalam menginternalisasikan nilai-nilai moral, religius; dan hanya bersfifat normatif tidak mengakar dan merespon perkembangan masyarakat; banyak peserta didik yang terlibat dalam perbuatan amoral dan asusila, seperti; tawuran, begal, penyalagunaan NARKOBA dan pergaulan bebas.

Atas dasar itulah, penulis merumuskan atau mengembangkan model strategi pembelajaran PAI yang bersifat integratif (nilai religius, sains dan teknologi) dalam 
merespon perkembangan masyarakat di eara digital sekarang ini. Tentunya, tulisan ini masih sangat terbatas dan perlu pengkajian serta penelitian lebih lanjut untuk mencapai konsep lebih fungsional dan komprehensif. 
Muhammad Tang, Pengembangan Strategi Pembelajaran Pendidikan Agama Islam (PAI) dalam Merespon Era Digital

\section{Daftar Pustaka}

Abdullah, Amin. 2004. Pengantar. dalam Imam Machali at al, Pendidikan Islam dan Tantangan Globalisasi: Buah Pikiran Seputar; Filsafat, Politik, Ekonomi, Sosial dan Budaya. Yogyakarta: PRESMA UIN Sunan Kalijaga.

Al-Faruki, Ismail Raji dalam Sutrisno. 2006. Pendidikan Islam yang menghidupkan:

Studi Kriti Terhadap Pemikiran Fazlurrahman, Yogyakarta: Kota Kembang.

Asy'arie, Musa. 2005. NKRI, Budaya Politik dan Pendidikan, Yogyakarta: LESFI.

David, J. R. dalam Pengawas. 2008. Strategi Pembelajaran dan Pemilihannya. Jakarta:

Direktorat Jenderal Tenaga Kependidikan Nasional.

Dewi, Laksmi \& Masitoh. 2009. Strategi Pembelajaran, Jakarta: DEPAG RI.

Elprida, Eka. 2015. Strategi Pembelajaran, Jurnal Pendidikan, Universitas Pendidikan Indonesia.Vol. 4. No 2.

Lou, Carey\& Dick Walter. 1994. The Systematic Desgn of Instruction, New York: Harper Collins.

Mulyasa, Encang. 2001. Kurikulum Berbasis Kompetensi. Remaja Rosda Karya: Bandung.

Peraturan Pemerintah (PP) Nomor 14 Tahun 2005, tentang Pendidik dan Dosen, pada BAB III pasal 7 ayat 1.

Peraturan Pemerintah (PP) Nomor 14 Tahun 2005, tentang Pendidik dan Dosen, pada BAB IV pasal 10 ayat 1.

Riyanto, Yatim. 2010. Paradigma Baru Pembelajaran: Sebagai Referensi bagi Pendidik/Pendidik dalam Implementasi Pembelajaran yang Efektif dan Berkualitas, Jakarta: Kencana.

Sanjaya, Wina. 2008. Kurikulum dan Pembelajaran: Teori dan Praktik Pengembangan Kurikulum Tingkat Satuan Pendidikan KTSP. Jakarta: Kencana.

Sukmadinata, Nanah Syaodih, 2016. Pengembangan Kurikulum Teori dan Praktik, Cet. XIX; Bandung: PT Remaja Rosda Karya,

Tilaar, H. A. R., 2000. Paradigma Baru Pendidikan Nasional, Jakarta: Rineka Cipta.

Yamin, Martinis. 2005. Strategi Pembelajaran Berbasis Kompetensi, Gaung Persada: Jakarta. 